BULLETIN Bulletin hispanique

HISPANIQUE Université Michel de Montaigne Bordeaux

119-1 | 2017

Autorité et pouvoir dans le théâtre du Siècle d'Or

\title{
Algunas aproximaciones a los modelos de autoridad y poder en el teatro del Siglo de Oro
}

Ignacio Arellano

\section{(2) OpenEdition}

1 Journals

\section{Edición electrónica}

URL: http://journals.openedition.org/bulletinhispanique/4722

DOI: 10.4000/bulletinhispanique.4722

ISBN: 979-10-300-0142-6

ISSN: 1775-3821

Editor

Presses universitaires de Bordeaux

Edición impresa

Fecha de publicación: 15 junio 2017

Paginación: 13-16

ISBN: 979-10-300-0141-9

ISSN: 0007-4640

\section{Referencia electrónica}

Ignacio Arellano, «Algunas aproximaciones a los modelos de autoridad y poder en el teatro del Siglo de Oro », Bulletin hispanique [En línea], 119-1 | 2017, Publicado el 15 junio 2017, consultado el 23

septiembre 2020. URL : http://journals.openedition.org/bulletinhispanique/4722 ; DOI : https://doi.org/ 10.4000/bulletinhispanique.4722

Este documento fue generado automáticamente el 23 septiembre 2020.

Tous droits réservés 


\title{
Algunas aproximaciones a los modelos de autoridad y poder en el teatro del Siglo de Oro
}

\author{
Ignacio Arellano
}

1 Amplios territorios en la literatura y el arte del Siglo de Oro se caracterizan por la exploración de los mecanismos del poder y sus límites, por el ejercicio de la autoridad y sus requisitos, por las intersecciones entre los ámbitos de la realidad y la producción literaria.

2 Es conocida la interpretación que defendió sobre todo José Antonio Maravall, quien veía en el teatro del Siglo de Oro una máquina de propaganda del poder. Las cosas, naturalmente, no son tan simples. No lo pueden ser en una sociedad y una cultura tan compleja y en la que florecieron dramaturgos como Lope y Calderón, o narradores como el mismo Cervantes, incapacitados para lo trivial. Que el teatro del Siglo de Oro defienda el sistema no se puede decir sin matizar múltiples aspectos. Hay muchos modos de defender un sistema en el que se cree (y de criticarlo si no se cree en él, e incluso de defenderlo sin creer en su bondad): uno de ellos, por ejemplo, denunciar las traiciones a los principios que lo sustentan, traiciones de las que se puede acusar hasta al mismo rey, convirtiéndose tal defensa en subversiva en la práctica por el paradójico mecanismo de reclamar la vigencia de unas estructuras que entran en proceso de descomposición y que no son respetadas por quienes están, teóricamente, a su servicio.

Por lo demás cada uno puede considerar que su defensa responde a lo justo, aunque muestren diversas perspectivas: apuntaré, por ejemplo, la postura ante el tiranicidio (inaceptable para los personajes de Tirso, justificado para los de Calderón).

4 Es obvia la existencia de comedias que exaltan los valores de la monarquía y la nobleza, pero también la de piezas de notable sentido crítico; baste remitir a Fuenteovejuna, El burlador de Sevilla o La estrella de Sevilla. Y no se pueden marginar los imperativos estrictamente artísticos que confluyen con los ideológicos. Hay que tener en cuenta en este terreno la diversidad de géneros, que marcan diferentes tratamientos de la 
autoridad y el poder: pues no solamente existe la cuestión ideológica; la preceptiva literaria impone igualmente sus leyes.

Los problemas del poder y la autoridad se integran en otros conflictos más allá de sus dimensiones políticas: conflictos generacionales de enfrentamiento padre/hijo; o conflictos entre las pasiones personales y las obligaciones que impone el desempeño del poder y la autoridad -uno de los grandes temas en el teatro de Calderón, por ejemplo.

6 No solo los reyes protagonizan tramas sobre los límites del poder: comendadores abusivos como el de Fuenteovejuna o capitanes brutales como el de El alcalde de Zalamea, o los padres caballeros particulares que pretenden forzar a sus hijas a matrimonios no deseados abundan en matices de la problemática.

7 De nuevo las soluciones dependen de los géneros, por lo que la inserción de la perspectiva temática en la genérica me parece fundamental y una de las vías provechosas de análisis: la desautorización de los padres necios de la comedia de capa y espada puede hacerse a través de su ridiculización y el ingenio de los protagonistas, pero la de los reyes en las tragedias de poder y de ambición plantea muy diferentes cuestiones doctrinales de teoría política.

El presente volumen del Bulletin hispanique aborda algunos -necesariamente solo unos pocos- de estos campos y problemas. No hace al caso reiterar lo que el discreto lector podrá ver desarrollado con más detalle en los propios estudios publicados. Me limitaré a subrayar la amplitud del arco contemplado: destaca la figura de Calderón ${ }^{1}$-cada día más reivindicado, con justicia, contra viejos tópicos ignorantes y acusaciones banales estribadas en ideologías que se resisten a morir-, pero no faltan análisis sobre autores y piezas menos estudiadas y que merece la pena recuperar, como el criollo Peralta Barnuevo, la Epístola de Amarilis a Belardo², Enríquez Gómez, Pérez de Montalbán o Lope de Liaño ${ }^{3}$.

9 Me complace advertir el interés que ha despertado en este conjunto una de las figuras consideradas nucleares del teatro áureo, pero generalmente atendido a lejana distancia de Lope o Calderón: varios de los artículos, en efecto, versan sobre Tirso de Molina, no solo sobre el Burlador y El condenado por desconfiado (Cancelliere), sino también sobre la traducción de piezas palatinas (Barone), comedias como Doña Beatriz de Silva (BouchibaFochesato), la más famosa de La prudencia en la mujer (Oteiza), o el curioso papel del dramaturgo en algunas luchas intestinas por el poder en instituciones como la Real Academia Española en siglos posteriores (Florit).

10 Y también merece la pena resaltar las aproximaciones a un dramaturgo ya de transición, heredero de Calderón, el poeta áulico Bances Candamo, especialmente preocupado por la función pedagógica del teatro como instrucción de los monarcas (Duarte, Oteiza), poeta que por las propias características de su obra es inexcusable en el examen del tema general propuesto.

11 No podía faltar tampoco la mirada sobre el teatro de Cervantes, de la que se encarga Jean Canavaggio.

12 Igualmente amplios y diversos son los enfoques, aunque todos quedan enmarcados en la perspectiva global de la autoridad y el poder: desde la anotación filológica que da pie a más profundas interpretaciones (Rodríguez Garrido) a las temáticas, morales, míticas y antropológicas (Cancelliere, Rull, Strosetzki, Suárez); las estrategias de comunicación (Aichinger); cuestiones genéricas y de convenciones (Arellano); los problemas de la traducción y trasposición a otros ambientes culturales (Barone); imágenes de las figuras 
que encarnan distintos modos de poder (Canavaggio, Bouchiba-Fochesato, Ferrer, Gavela, Oteiza); la pervivencia o caducidad de modelos (Escudero, Florit); la relación teoría/práctica (Duarte); sin olvidar un asunto tan clásico como la voltaria fortuna de los privados (Cull) o el análisis de un símbolo igualmente nuclear en la tradición de la emblemática política como el del caballo (Kaufmant).

En fin, muchos análisis de obras, teóricas y literarias, quedan todavía por hacer, lo que permitirá comprender mejor el funcionamiento de estos mecanismos del poder y la autoridad en sus múltiples dimensiones.

A contribuir modestamente a ese propósito responden estas páginas, que ven la luz gracias a la acogida generosa del Bulletin hispanique, y su directora, Nadine Ly. Nos honra publicar estos trabajos en tan prestigiosa publicación.

Debo mencionar, finalmente, que esta investigación se inserta en el marco del proyecto FFI2014-52007-P, «Autoridad y poder en el teatro del Siglo de Oro. Estrategias, géneros, imágenes en la primera globalización», financiado por el Ministerio de Economía y Competitividad; y de la «Red del Patrimonio Teatral Clásico Español» (FFI2015-71441REDC) del Plan Nacional de Investigación Científica, Desarrollo e Innovación Tecnológica del Gobierno de España, organismo cuya ayuda nos complace también reconocer.

\section{NOTAS}

1. Ver los artículos de Aichinger, Rull, Strosetzki, Suárez Miramón.

2. Trabajos de Rodríguez Garrido y Vinatea que introducen la necesaria perspectiva trasatlántica.

3. Para estos últimos ver los artículos de González Cañal, Cull y Mata.

\section{AUTOR}

\section{IGNACIO ARELLANO}

GRISO-Universidad de Navarra 